\title{
Use of Agro Waste Biomass for $\alpha$-Amylase Production by Anoxybacillus amylolyticus: Purification and Properties
}

Ilaria Finore ${ }^{1}$, Paola Di Donato ${ }^{1,2}$, Annarita Poli' ${ }^{1}$, Betul Kirdar ${ }^{3}$, Ceyda Kasavi ${ }^{3}$, Ebru O Toksoy ${ }^{4}$, Barbara Nicolaus ${ }^{1}$ and Licia Lama $^{1 *}$

${ }^{1}$ CNR-National Research Council of Italy, Institute of Biomolecular Chemistry, Via Campi Flegrei 34, 80078 Pozzuoli, NA, Italy

${ }^{2}$ Department of Sciences and Technology, University of Naples "Parthenope" Centro Direzionale Napoli (Isola C4) 80143 Naples, Italy

${ }^{3}$ Department of Chemical Engineering, Bogazici University, Bebek, 34342 Istanbul, Turkey

${ }^{4}$ Department of Bioengineering, Marmara University, Goztepe Campus, 34722 Istanbul, Turkey

\begin{abstract}
Knowledge accumulated from fundamental and applied studies on Anoxybacillus suggests that this genus can serve as a good alternative in many applications related to starch and lignocellulosic biomasses, waste treatment, enzyme technology, and bioenergy production.

We investigated the purification, biochemical characterization and immobilization of a thermostable $\alpha$-amylase from the thermophilic Anoxybacillus amylolyticus, strain MR3CT, isolated in Antarctica and its production on vegetable wastes. In particular, the rhizome from Arundo donax, waste biomass of Cynara cardunculus and potato peels were tested either in Submerged Fermentation (SmF) and Solid State Fermentation (SSF) conditions.

The amylase from $A$. amylolyticus, with a molecular weight of about $60 \mathrm{kDa}$, displayed an optimum enzyme activity at $60^{\circ} \mathrm{C}$ and $\mathrm{pH} 5.6$. Moreover, by retaining up to $70 \%$ of total activity after $48 \mathrm{~h}$ at $60^{\circ} \mathrm{C}$, it showed high thermostability in the presence of $2 \mathrm{mM}$ calcium ion. The immobilized enzyme maintained the $48 \%$ of its initial activity after the sixth reuse. The optimal conditions for its production in $\mathrm{SmF}$ were achieved at $60^{\circ} \mathrm{C}$ for $24 \mathrm{~h}$ with $1 \%$ of rhizome from Arundo donax, which was about $2126 \mathrm{U} / \mathrm{gds}$. SSF cultures reached maximum a-amylase yield (102 $\mathrm{U} / \mathrm{gds}$ ) when grown on waste biomass of Cynara cardunculus as substrate, with a substrate-water ratio of 1:1 (w/v), and incubation at $60^{\circ} \mathrm{C}$ for 4 days. In this study, rhizome of $A$. donax resulted to be a good substrate for amylase production in $\mathrm{SmF}$ thus allowing a cheaper alternative to obtain amylolytic enzymes. Indeed by using rhizomes from $A$. donax as growth substrate it was possible to recovery an amylase activity level higher than that obtained by synthetic complex medium. Amylase production was also investigated under SSF conditions by using the above listed wastes as sole carbon source for $A$. amylolyticus growth. Under these conditions, $C$. cardunculus gave a higher enzyme yield per reactor volume.
\end{abstract}

Keywords: Anoxybacillus amylolyticus; Vegetable wastes; Amylases; SSF; SmF; Immobilization

\section{Introduction}

a-Amylase (E.C 3.2.1.1) catalyses the hydrolysis of $\alpha$-D-(1,4) glycosidic linkages in starch components and related carbohydrates. Amylases are among the most important enzymes in global market that have potential application in a number of industrial processes such as food, pharmaceuticals, cosmetics, fermentation, textile and paper industries. Although they can be derived from different sources, including microorganisms, plants and animals, microbial enzymes generally meet industrial demands. The performance, economics and feasibility of each $\alpha$-amylase applications is influenced by important enzyme characteristics, including specificity, stability, optimum temperature and $\mathrm{pH}$ performance [1]. Therefore, selection of the suitable microbial strains which produce enzymes that show good activity and stability at industrially desirable conditions will be valuable.

Although, amylase has been produced by Submerged Fermentation (SmF), Solid State Fermentation (SSF) has remarkable potential for the production of industrial enzymes in view of its economic and engineering advantages. It can be of particular significance in those processes where a crude product may be used as an enzyme source [2]. Agroindustrial residues are generally considered the best substrates for the SSF processes and enzyme production. In fact, the use of SSF for the production of enzymes and other products has many advantages over SmF [3,4] and these have been widely discussed in the literature [5]. Such systems have proved more efficient in the production of several enzymes and metabolites by microbes, as they more closely mimic the microbes' natural habitat. This cultivation technique has acquired a special relevance in the field of biotechnology because it gives higher productivity per reactor volume, has lower operating costs, produces less wastewater, less demands in terms of energy and space, requires simpler equipment, gives higher product concentration, avoids foaming and lowers the risks of contamination [6,7].

In the light of these, our extremophiles data bank collection has been screened to identify species able to produce amylolytic enzymes. This report describes purification, biochemical characterization and immobilization of a thermostable $\alpha$-amylase by the extremophile Anoxybacillus amylolyticus, strain MR3CT [8], a thermophilic species isolated in Antarctica and its production, either in Submerged Fermentation (SmF) and Solid State Fermentation (SSF) conditions. The enzyme production were investigated in relation to different kinds of raw vegetable waste biomass, i.e. potato peeling residues, rhizomes of Arundo donax and biomass from Cynara cardunculus as growth medium.

*Corresponding author: Licia Lama, CNR-National Research Council of Italy, Institute of Biomolecular Chemistry, Via Campi Flegrei 34, 80078 Pozzuoli, NA, Italy, Tel: +39 06 49931; E-mail: Ilama@icb.cnr.it

Received June 16, 2014; Accepted July 23, 2014; Published July 30, 2014

Citation: Finore I, Donato PD, Poli A, Kirdar B, Kasavi C, et al. (2014) Use of Agro Waste Biomass for a-Amylase Production by Anoxybacillus amylolyticus: Purification and Properties. J Microb Biochem Technol 6: 320-326. doi:10.4172/1948-5948.1000162

Copyright: (c) 2014 Finore I, et al. This is an open-access article distributed under the terms of the Creative Commons Attribution License, which permits unrestricted use, distribution, and reproduction in any medium, provided the original author and source are credited 


\section{Materials and Methods}

\section{Microorganism}

Anoxybacillus amylolyticus, strain MR3CT (ATCC BAA$872 \mathrm{~T}=\mathrm{DSM} 15939 \mathrm{~T}=\mathrm{CIP} 108338 \mathrm{~T})$, was cultivated at $60^{\circ} \mathrm{C}$ on $\mathrm{YN}$ complex medium containing (w/v): $0.6 \%$ yeast extract, $0.6 \% \mathrm{NaCl}$ at pH 5.6 (standard growth conditions) [8]. Growth was followed for $24 \mathrm{~h}$ by measuring the optical densities at $540 \mathrm{~nm}$. For amylase purification, the bacterial culture was grown on SS complex medium containing $(\mathrm{w} / \mathrm{v}): 0.6 \%$ yeast extract, $0.6 \% \mathrm{NaCl}, 0.2 \%$ soluble starch in the above $\mathrm{pH}$, temperature and time course conditions.

\section{a-Amylase assay and protein determination}

The amylase activity was assayed as previously described [9], incubating at $60^{\circ} \mathrm{C}$ for $10 \mathrm{~min} 0.1 \mathrm{ml}$ of appropriately diluted enzyme solution, $0.4 \mathrm{ml}$ solution of $0.25 \%$ starch (w/v) in $50 \mathrm{mM}$ acetate buffer $\mathrm{pH}$ 5.6. One unit of amylase activity was defined as the amount of the enzyme causing $10 \%$ reduction in starch-iodine color in $10 \mathrm{~min}$ in the standard assay conditions. Enzyme activity was expressed in terms of units per gram dry substrate $\left(\mathrm{U} \mathrm{gds}^{-1}\right)$. The total protein content was determined according to Bradford method [10]. All values given are averages of three assays

\section{Biomasses}

Potato peel wastes were obtained from local market. The biomass was first washed with tap water and then with distilled water in order to remove surface dust particles. After washing, a blanching operation was carried out by immersing them into hot water at $75-80^{\circ} \mathrm{C}$ for $20 \mathrm{~min}$, followed by a drying step in an oven at $45^{\circ} \mathrm{C}$ [11]. Rhizomes of Arundo donax and biomass of Cynara cardunculus, were kindly provided by the Agraria Department of "Federico II" University, Naples. Rhizomes of Arundo donax and biomass of Cynara cardunculus, were provided by the Agraria Department of "Federico II" University, Naples and were obtained from an experimental plantation located in Bellizzi (SA). The three biomasses were grinded at $4 \mathrm{~mm}$. Successively, in order to obtain a homogenous fine powder (particle size of about $1 \mathrm{~mm}$ ) the material was further grinded by means of a Waring Blender mixer and stored at room temperature until used.

\section{Optimization of fermentation conditions}

Amylase production was investigated both in SmF (1) and in SSF (2) condition growing A. amylolyticus on different carbon sources including vegetable wastes.

(1) The effect of different carbon sources on amylase production was observed in the media containing (\% w/v) $0.6 \mathrm{NaCl}$ and one of the following substrates $(\% \mathrm{w} / \mathrm{v}): 0.6$ yeast extract $(\mathrm{YN}) ; 0.6$ yeast extract +0.2 soluble starch (SS); one of the following vegetable waste sources (\% w/v): 1.0 potato peel wastes (PP); 1.0 rhizomes of Arundo donax (AD); 1.0 biomass of Cynara cardunculus (CC). The $\mathrm{pH}$ was adjusted at 5.6. All experiments were carried out in triplicate in $1 \mathrm{~L}$-flasks filled with $100 \mathrm{~mL}$ of broth culture and incubated at $60^{\circ} \mathrm{C}$ for $24 \mathrm{~h}$. Cells were removed in late exponential growth phase, and the supernatants obtained by centrifugation at $10000 \mathrm{rpm}$ for $30 \mathrm{~min}$ were used for protein content and amylase activity determinations.

(2) The production of $\alpha$-amylase under SSF was studied utilizing the following vegetable wastes as substrate: potato peel wastes (PP), rhizomes of Arundo donax (AD) and biomass of Cynara cardunculus (CC). The strategy was to optimize each parameter independently and employ optimal conditions subsequently in all experiments for every substrate. $1 \mathrm{gr}$ of each crude substrate was taken in $100 \mathrm{ml}$ Erlenmeyer flask and to this distilled water was added according to $1: 1 \mathrm{w} / \mathrm{v}$ ratio and sterilized at $121^{\circ} \mathrm{C}$ for $20 \mathrm{~min}$. After cooling, they were inoculated with $2 \mathrm{~mL}$ of $24 \mathrm{~h}$ old culture in $\mathrm{YN}$ medium and observing the effects after $72 \mathrm{~h}$ of incubation at $60^{\circ} \mathrm{C}$, unless otherwise stated.

The parameters, which were optimized for maximal enzyme production, were: the ratio $(\mathrm{w} / \mathrm{v})$ of the solid substrate to the moisturizing agent (1:1,1:1.5, 1:2); the inoculum size: 1,2 and $3 \mathrm{~mL}$ of culture, in order to obtain an average optical density at $540 \mathrm{~nm}$ of 0.700; substrate size: 1 and $4 \mathrm{~mm}$; incubation time: $1,2,3,4,5$ and 6 days. In separate experiments, instead of water, moisturizing agents were made up by aqueous solution containing one of the following sources $\left(\mathrm{NH}_{4}\right) 2 \mathrm{SO}_{4}, \mathrm{NaNO}_{3}$, yeast extract, peptone, $\left(\mathrm{NH}_{4}\right) \mathrm{Cl},\left(\mathrm{NH}_{4}\right)$ $\mathrm{NO}_{3}$ at $1 \%(\mathrm{w} / \mathrm{w})$, or vitamin solution and metal solution (DSM 141) at $0.1 \%(\mathrm{v} / \mathrm{w})$, with the respect the weight of solid substrate used.

To assess bacterial biomass production, fermented substrates were suspended in $12.5 \mathrm{ml}$ of $50 \mathrm{mM}$ acetate buffer $\mathrm{pH} 5.6$, and centrifuged at $10000 \mathrm{rpm}$ for $30 \mathrm{~min}$; the supernatants were used for protein content and amylase activity determinations. All optimization experiments were run in triplicate.

\section{Statistical analysis}

Statistical significance of results for growth analysis and enzyme assay in SmF was assessed by t test by means of SYSTAT 7.0 software. For both parameters the analysis comparison was made for all tested media with respect to YN complex medium and each one respect to the other media.

\section{Amylase purification}

$500 \mathrm{ml}$ of MR3CT culture broth on SS complex medium were centrifuged at $10000 \mathrm{rpm}$ for $30 \mathrm{~min}$ and the cell-free supernatant was precipitated with $80 \%$ ammonium sulphate. The crude enzyme was then loaded onto a Q-Sepharose Fast Flow $(1.6 \times 27 \mathrm{~cm}$, Pharmacia) column pre-equilibrated in $50 \mathrm{mM}$ sodium acetate, $\mathrm{pH}$ 5.6. Bound proteins were eluted at a flow rate of $3 \mathrm{ml} \mathrm{min}^{-1}$ by applying a linear $\mathrm{NaCl}$ gradient $(0-1 \mathrm{M} \mathrm{NaCl}$ in $50 \mathrm{mM}$ sodium acetate, $\mathrm{pH} 5.6$ ). The collected fractions with alpha-amylase activity were pooled, concentrated by ultrafiltration (Amicon, YM 10) and then dialyzed against the some buffer. The amylase sample recovered from the anion exchange chromatography, was purified by Pharmacia FPLC (ÄKTA, Amersham, Biosciences) system equipped with a pre-packed $16 / 60$ Sephacryl S-100 column (Pharmacia), pre-equilibrated in $50 \mathrm{mM}$ sodium acetate buffer, pH 5.6 containing $150 \mathrm{mM} \mathrm{NaCl}$. Elution was performed with the same buffer at a flow rate of $0.5 \mathrm{ml} \mathrm{min}^{-1}$ and active fractions were pooled, concentrated by ultrafiltration (Amicon, YM 10) and dialyzed against the same buffer.

\section{Electrophoresis analysis and zymogram}

Protein samples were analyzed by sodium dodecyl sulfatepolyacrylamide gel electrophoresis (SDS-PAGE) using 15\% gels according to the method of Laemmli [12] and zymographic analysis [13]. The molecular mass was determined by using a low molecular weight protein marker (Pharmacia). The relative molecular mass of the enzyme was determined by gel filtration chromatography on a Sephacryl S-100 column (Pharmacia), using a standard gel filtration calibration kit (Pharmacia).

\section{Biochemical characterization of amylase}

To study the $\mathrm{pH}$ effect, the enzyme was incubated at $60^{\circ} \mathrm{C}$ at 
different $\mathrm{pH}$ values ranging from 3.0 to $\mathrm{pH} 10.0$ by means of the following buffers: $50 \mathrm{mM}$ glycine- $\mathrm{HCl}(\mathrm{pH} 3.0) ; 50 \mathrm{mM}$ acetate $(\mathrm{pH}$ 3.5, 4.0, 5.0, 5.6); $50 \mathrm{mM}$ phosphate (pH 6.0, 6.5, 7.0, 7.6, 8.0); $50 \mathrm{mM}$ glycine- $\mathrm{NaOH}(\mathrm{pH} 9.0,10.0)$. To study the temperature effect, activity assay was performed at $\mathrm{pH} 5.6$ by varying the incubation temperatures from $30^{\circ} \mathrm{C}$ to $90^{\circ} \mathrm{C}$.

The effect of $\mathrm{Ca}^{2+}$ on the amylase thermostability was evaluated by treating the purified enzyme at $60^{\circ} \mathrm{C}$ in the presence of $2 \mathrm{mM} \mathrm{CaCl}_{2}$ for various time intervals, until max $96 \mathrm{~h}$, then the residual enzyme activity was determined under standard assay conditions.

To study the effect of metals, additives and enzyme inhibitors on amylase activity purified amylase was pre-incubated, before enzyme assay, for $30 \mathrm{~min}$ at room temperature in the presence of one of the follow ions: $2 \mathrm{mM} \mathrm{Hg}{ }^{2+}, \mathrm{Fe}^{2+}, \mathrm{Co}^{2+}, \mathrm{Ba}^{2+}, \mathrm{Mg}^{2+}, \mathrm{Mn}^{2+}, \mathrm{Ca}^{2+}$, (in chloride form), $\mathrm{Zn}^{2+}$ and $\mathrm{Cu}^{2+}$ (in sulphate form). Different additives and inhibitors were tested including: EDTA $(5 \mathrm{mM}, 10 \mathrm{mM})$, Urea $(2 \mathrm{M}$, $4 \mathrm{M})$, N-Bromosuccinimide (NBS) $(10 \mathrm{mM}), \beta$-mercaptoethanol (10 $\mathrm{mM}, 20 \mathrm{mM})$, SDS $(0.1 \% \mathrm{w} / \mathrm{v}, 0.2 \% \mathrm{w} / \mathrm{v})$ and Triton $\mathrm{X}-100(0.1 \%$ $\mathrm{w} / \mathrm{v}, 0.2 \% \mathrm{w} / \mathrm{v})$. The amylase assay was carried out under standard conditions; the activity measured in the absence of metal ions was taken as the $100 \%$ reference value.

\section{Analysis of Hydrolysis Products}

a-Amylase was incubated at $60^{\circ} \mathrm{C}$ in $50 \mathrm{mM}$ acetate buffer $\mathrm{pH} 5.6$ in the presence of $(1 \% \mathrm{w} / \mathrm{v})$ soluble starch. Incubation was carried out for $20 \mathrm{~min}, 2,6$ and $24 \mathrm{hrs}$ by stopping the reactions in ice-cold bath. The hydrolysis products were analysed by TLC chromatography (eluant n-buthanol/ acetic acid/ water 6:2:2, v/v/v), the bands were revealed by the alpha-naphtol-sugars reactions, followed by heating at $150^{\circ} \mathrm{C}$ for $5 \mathrm{~min}$.

\section{Entrapment of amylase and its reuse}

Entrapment of amylase was carried out as described previously [14]. $0.5 \mathrm{~mL}$ of crude enzyme solution and $3.5 \mathrm{~mL}$ of $2 \%(\mathrm{w} / \mathrm{v})$ sodium alginate (medium viscosity) were mixed and extruded dropwise through a syringe $(0.8 \mathrm{~mm}$ diameter) into a $200 \mathrm{~mL}$ of a gently stirred $100 \mathrm{mM} \mathrm{CaCl}$ solution for $30 \mathrm{~min}$ at $4^{\circ} \mathrm{C}$. The calcium alginate beads containing the enzyme were separated from the $\mathrm{CaCl}_{2}$ solution by filtration. They were washed on a filter, three times with $10 \mathrm{mM} \mathrm{CaCl}$ in $50 \mathrm{mM}$ sodium acetate buffer, $\mathrm{pH}$ 5.6. The bead diameter ranged from 2 to $3 \mathrm{~mm}$.

The immobilized crude enzyme was assayed as described before.

In order to test the reuse of entrapped $a$-amylase, the activity in the beads was assayed several times for the hydrolysis of soluble starch. After each amylase activity assay of the beads, they were removed, washed thoroughly with distilled water and stored at $4^{\circ} \mathrm{C}$. Then, the beads were reassayed for $a$-amylase activity and the same process was repeated till the sixth use. The decrease in activity for each cycle was determined assuming activity of beads in the first cycle as $100 \%$.

\section{Sequencing of $\alpha$-amylase}

The gene coding for the $\alpha$-amylase from Anoxybacillus amylolyticus was amplified according as previously [9]. The sequence obtained was deposit in DNA Data Bank of Japan.

\section{Results and Discussions}

\section{Growth and enzymatic production on SmF}

The effect of the carbon sources on growth and enzymatic production on $\mathrm{SmF}$ was studied by growing the microorganism in a medium containing different carbon sources including agriculture wastes. In these conditions, Soluble Starch (SS) gave highest biomass production $(26.3 \pm 0.6 \mathrm{mg}$ of total protein) (Table 1$)$.

In terms of amylase activity, $\mathrm{AD}$ resulted as the best inducer source (2126 $\left.\pm 26 \mathrm{U} \mathrm{gds}^{-1}\right)$, which was 2,2-fold higher than the activity in standard growth medium YN $\left(965 \pm 9 \mathrm{U} \mathrm{gds}^{-1}\right)$, and almost comparable to that recovery by SS media; CC resulted poor inducer giving the lowest yield in terms of growth and amylase activity $(8.7 \pm 0.1 \mathrm{mg}$ of total protein and $\left.575 \pm 11 \mathrm{U} \mathrm{gds}^{-1}\right)$.

\section{Production of enzyme under SSF}

The use of Solid State Fermentation (SSF) represents an alternative and low cost production method. SSF holds tremendous potential for the production of enzyme and it can be of special interest in those processes where crude fermented product may be used as enzyme source [3-5]. For amylase production on SSF each carbon source was studied independently by varying various physicochemical and cultural conditions.

During the time course study, enzyme activity was detected in the culture supernatant from $24 \mathrm{~h}$ to $144 \mathrm{~h}$, and the maximum $\alpha$-amylase production was found for all substrates tested after $96 \mathrm{~h}$. After that, a significant decrease was observed which could be due to denaturation of enzyme as already observed in other studies [15] or to the presence of secondary metabolites produced at the end of the stationary phase and toxic for the microorganism, thus resulting in a lower yield of enzyme. This value was comparable to the amylase production reached in SSF conditions by other species of Bacillus [16,17]. Therefore, 96 hours was the incubation time used in later studies.

The inoculum size was evaluated because it is also an important factor for production of $\alpha$-amylase [18]. The results showed that there was a significant increase in $\alpha$-amylase production with an increase in inoculum size up to an optimum level after which growth and enzyme yield decreased. Indeed maximum enzyme production was obtained with an inoculum size of $2 \mathrm{~mL}$ of preculture for all substrates tested. The decrease seen with larger inoculum sizes could be due to an early competition for nutrients among the cell population, as observed in Bacillus firmus-I-4071 [19] and T. harzianum [20].

Another crucial factor in SSF is the substrate moisture and its importance for enzyme production has been well established [21]. The moisture content of the medium changes during fermentation as a result of evaporation and metabolic activities, and the moisture level of the substrate is therefore essential [22]. The critical importance of moisture level in SSF media and its influence on the biosynthesis and secretion of enzymes can be attributed to the interference of moisture in the physical properties of the solid particles [18]. Low and high moisture levels of the substrate affect the growth of the microorganism

\begin{tabular}{|l|c|c|}
\hline Growth media & Growth (mg of total protein) & Activity (U/gds) \\
\hline YN & $16.6 \pm 0.3$ & $965 \pm 9$ \\
\hline SS & $26.3 \pm 0.6$ & $1904 \pm 33$ \\
\hline PP & $10.75 \pm 0.3$ & $1000 \pm 26$ \\
\hline AD & $9.4 \pm 0.2$ & $2126 \pm 24$ \\
\hline CC & $8.7 \pm 0.1$ & $575 \pm 11$ \\
\hline
\end{tabular}

Table 1: Effect of different carbon sources (YN: yeast extract; SS: soluble starch; PP: potato peels; AD: rhizomes of Arundo donax; CC biomass of Cynara cardunculus) on $A$. amylolyticus growth and amylase production after $24 \mathrm{~h}$ of incubation at $60^{\circ} \mathrm{C}$ in $\mathrm{SmF}$ conditions. The values are the average of two assays. Significance was determined by t test for all media versus $\mathrm{YN}$ complex medium and for each medium respect to the other media. $\mathrm{P}$ resulted $<0.01$ for all comparison media. 
resulting in lower enzyme production [23]. The ratio 1:1 (w/v) resulted the best for amylase production in presence of CC; while for PP and $\mathrm{AD}$ 1:1.5 (w/v) was the most suitable moistening ratio. Therefore, the moistening ratio described above for each substrate was used to investigate the effect of substrate particle size $(\mathrm{mm})$ on $\alpha$-amylase production in further studies.

In the SSF processes, particle size is the most significant for microbial growth and activity [24]. The maximum enzyme production for every substrates was found to be at $4 \mathrm{~mm}$ particle size. With smaller particles $(1 \mathrm{~mm})$, the surface area for growth is greater, and thus it should be considered as a desirable factor. However, too small particles may result in substrate agglomeration in most cases, which interfere with aeration and may thus result in poor growth. At the same time, larger particles provide better aeration efficiency, but provide limited surface for microbial attack [25]. Hence, it is stated that determination of particle size corresponding to optimum growth and enzyme production is necessary [23]. Thus, $4 \mathrm{~mm}$ particle size of substrate was used to select the most suitable moistening agent.

Among the various agents tested in this study, distilled water was found to be the best agent to moisturize $\mathrm{AD}$ while vitamin solution was found to be the most favorable for CC and $\left(\mathrm{NH}_{4}\right) 2 \mathrm{SO}_{4}$ is the moistening agent that was the most effective for the production of $a$-amylase for PP.

Definitively, maximum amylase yield $\left(102 \mathrm{U} \mathrm{gds}^{-1}\right)$ was obtained with CC, by using vitamin solution as moistening agent with ratio 1:1 (w/v) (Table 2).

$\mathrm{PP}$ was the second best amylase inducer, about one third of enzyme recovered by CC, with $\left(\mathrm{NH}_{4}\right) 2 \mathrm{SO}_{4}$ solution as moistening agent in the ratio 1:1.5 (w/v). The lowest amylase recovery was observed with $\mathrm{AD}$ as substrate with 1:1.5 (w/v) moistening ratio; distilled water gave the higher amylase production with this waste source.

\section{Comparison between SmF and SSF}

Although a direct comparison between SmF and SSF modes is difficult to make because the two processes are different, it results evident that one of the most ecological (environment-protective) advantage of SSF is due to the fact that it is conducted in the absence of a free aqueous phase. This result in minimum water consumption and thus a low production of effluent water by the process, minimizing the contamination risk and therefore the possibility to perform the fermentation under semi-sterile conditions. This means that, energy- and instrumentation-demanding sterilization processes can be reduced or eliminated [26]. Figure 1 shows the comparison of amylase production from Anoxybacillus amylolyticus in SmF and SSF in function of water volume employed during the growth. From this point of view the biomass from Cynara cardunculus resulted as best substrate in SSF with a highest enzyme yield.

In addition, all the waste biomass afforded suitable microbial biomass production and moreover they positively affected also production of enzymes by the studied extremophilic Anoxybacillus

\begin{tabular}{|l|c|c|}
\hline Growth media & Growth (mg of total protein) & Activity (U/gds) \\
\hline PP & $0.55 \pm 0.01$ & $32 \pm 0.9$ \\
\hline AD & $0.87 \pm 0.02$ & $7 \pm 0.01$ \\
\hline CC & $1.4 \pm 0.03$ & $102 \pm 1.9$ \\
\hline
\end{tabular}

Table 2: Effect of different carbon sources (PP: potato peels; AD: rhizomes of Arundo donax; CC biomass of Cynara cardunculus) on $A$. amylolyticus growth and amylase production after 96 hours of incubation at $60^{\circ} \mathrm{C}$ in optimal SSF conditions for each substrate. The values are the average of two assays.

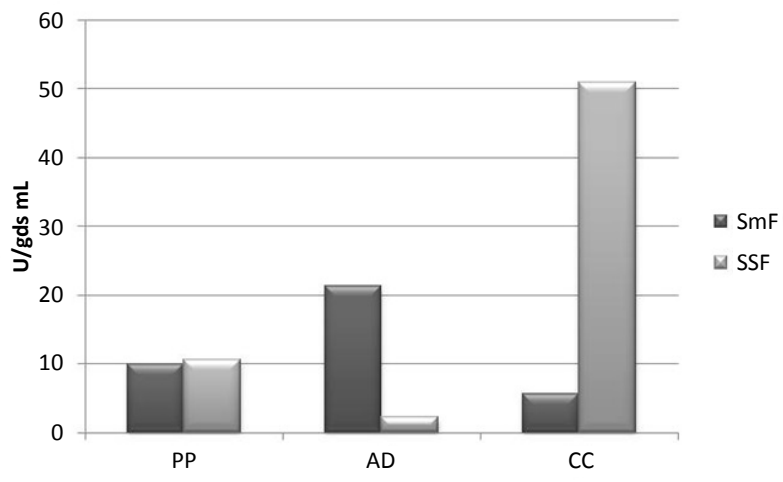

Figure 1: SmF and SSF comparison.

Amylase yield expressed as enzyme unit per gram of substrate per water volume applied during $A$. amylolyticus SmF and SSF processes. PP: potato peels; AD: rhizomes of Arundo donax; CC: biomass of Cynara cardunculus.

\begin{tabular}{|l|c|c|c|c|c|}
\hline $\begin{array}{l}\text { Purification } \\
\text { step }\end{array}$ & $\begin{array}{c}\text { Total } \\
\text { protein (mg) }\end{array}$ & $\begin{array}{c}\text { Total activity } \\
(\mathbf{U})\end{array}$ & $\begin{array}{c}\text { Specific } \\
\text { activity (U/mg) }\end{array}$ & $\begin{array}{c}\text { Purification } \\
\text { (fold) }\end{array}$ & $\begin{array}{c}\text { Yield } \\
\text { (\%) }\end{array}$ \\
\hline$\left(\mathrm{NH}_{4}\right)_{2} \mathrm{SO}_{4}$ & 118 & 7533 & 63 & 1 & 100 \\
\hline $\begin{array}{l}\text { Q-Sepharose } \\
\text { F.F. }\end{array}$ & 5 & 4578 & 915.6 & 14.5 & 61 \\
\hline $\begin{array}{l}\text { Sephacryl } \\
\text { S-100 }\end{array}$ & 0.024 & 1722 & 71750 & 1138 & 23 \\
\hline
\end{tabular}

Table 3: Purification of amylase from A. Amylolyticus.

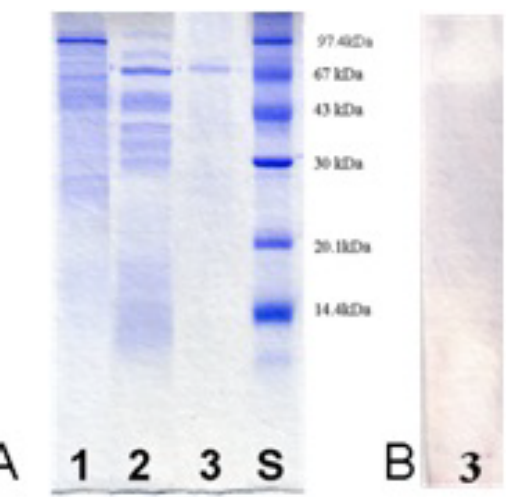

Figure 2: SDS-PAGE after staining with blue Coomassie and zymogram. (A) SDS-Page (15\%): lane 1, partially purified sample by ammonium sulphate precipitation; lane 2-purified amylase after anion exchange chromatography; lane 3-purified amylase after gel filtration chromatography; lane S-standard protein markers (LMW); B) lane 3-zymogram of purified amylase after gel filtration chromatography.

amylolyticus. The results obtained encourage exploiting such wastes as zero cost fermentation media for biotechnologically useful $\alpha$-amylase, thus also providing an alternative and less environmental impacting method for vegetable wastes management.

\section{Purification of extracellular $\alpha$-amylase}

Amylase was purified, from the growth of A. amylolyticus on SS complex medium, via three chromatographic steps and data regarding each step are summarized in Table 3 . The applied protocol yielded a purified fraction with a specific activity of $71750 \mathrm{U} / \mathrm{mg}$ of proteins, a purification factor of 1138 and a yield of $23 \%$. Gel filtration chromatography showed that amylase has a molecular weight of about $60 \mathrm{kDa}$ as also confirmed by SDS-PAGE of the purified fractions, which additionally established a single polypeptide chain structure 
Citation: Finore I, Donato PD, Poli A, Kirdar B, Kasavi C, et al. (2014) Use of Agro Waste Biomass for a-Amylase Production by Anoxybacillus amylolyticus: Purification and Properties. J Microb Biochem Technol 6: 320-326. doi:10.4172/1948-5948.1000162

for this protein (Figure 2A). The purified enzyme was also subjected to zymographic analysis (Figure $2 \mathrm{~B}$ ): the clear halo, due to starch digestion, was observed at about $60 \mathrm{kDa}$ thus confirming the presence of amylase activity.

\section{Biochemical characterization of amylase}

The enzyme was active in the acidic to neutral $\mathrm{pH}$ range, showing the optimum value at $\mathrm{pH} 5.6$ and retaining about $50 \%$ of its original activity at $\mathrm{pH} 4.5$ and 7.5. The optimum activity of the enzyme at acidic $\mathrm{pH}$ values makes this enzyme suitable for industrial applications $[27,28]$ since it would also avoid the required $\mathrm{pH}$ adjustment step when going from the liquefaction to the saccharification step, thus resulting in an overall simplification of the process [29].

The influence of temperature on enzyme activity was observed by incubating the enzyme in standard conditions at different temperatures ranging from $30^{\circ} \mathrm{C}$ to $90^{\circ} \mathrm{C}$. The maximal activity was found at $60^{\circ} \mathrm{C}$. In addition, the enzyme was active even at $80^{\circ} \mathrm{C}$, retaining at that temperature about the $60 \%$ of total activity.

The thermal stability of the enzyme was studied by assaying the activity in standard conditions, after sample pre-incubation for different intervals of time, at $60^{\circ} \mathrm{C}$ with and without calcium. Like other amylases, the isolated enzyme was more thermostable in the presence of $\mathrm{Ca}^{2+}$ than without it [1]. Indeed, the half-life was reached after $65 \mathrm{~h}$ of incubation at $60^{\circ} \mathrm{C}$, while in the presence of $2 \mathrm{mM}$ calcium ions it was $130 \mathrm{~h}$.

The influence of different divalent metal cations was investigated. The amylase activity was almost completely inhibited in the presence of $\mathrm{Hg}^{2+}$ as already observed for other microbial $\alpha$-amylases $[23,30]$ and this effect should suggest a possible involvement of indole amino acid residues in enzyme function [31]. Specific activity was also significantly lowered by the presence of $2 \mathrm{mM} \mathrm{Cu}^{2+}$; a similar effect was observed for Lactobacillus manihotivorans, for Bacillus circulans [32] and Bacillus coagulans enzymes [33]. Except for $\mathrm{Zn}^{2+}$, which was responsible of a $10 \%$ decrease of the activity, all the other tested metals and in particular $\mathrm{Ca}^{2+}, \mathrm{Fe}^{2+}$ and $\mathrm{Mn}^{2+}$ slightly stimulated the amylase activity (Table 4 ).

The effect of metal chelators, denaturing agents and detergents on specific activity was also investigated (Table 5).

The addition of $5 \mathrm{mM}$ EDTA resulted in about $70 \%$ activity inhibition thus confirming that metal play a fundamental role in the enzyme function. The amylase was insensitive to $\beta$-mercaptoethanol, which might suggest that disulfide bonds are not involved in preserving the enzymatic structure; it was totally inactivated by $10 \mathrm{mM}$ $\mathrm{N}$-bromosuccinimide, indicating the existence of essential tryptophan residues in the active site. Triton as well as SDS did not affect the activity and such resistance to detergents could make the MR3CT amylase a

\begin{tabular}{|c|c|}
\hline Metal concentration $\mathbf{( 2} \mathbf{~ m M})$ & Relative enzyme activity (\%) \\
\hline None & 100 \\
\hline $\mathrm{Hg}^{2+}$ & 1.3 \\
\hline $\mathrm{Fe}^{2+}$ & 122.4 \\
\hline $\mathrm{Co}^{2+}$ & 120 \\
\hline $\mathrm{Cu}^{2+}$ & 14.2 \\
\hline $\mathrm{Ba}^{2+}$ & 116.4 \\
\hline $\mathrm{Mg}^{2+}$ & 103 \\
\hline $\mathrm{Mn}^{2+}$ & 123.8 \\
\hline $\mathrm{Zn}^{2+}$ & 90.8 \\
\hline $\mathrm{Ca}^{2+}$ & 129 \\
\hline
\end{tabular}

Table 4: Effect of various metal salts on the activity of $\alpha$-amylase.

\begin{tabular}{|l|c|c|}
\hline Additives and Inhibitors & Concentration & Relative enzyme activity (\%) \\
\hline Control* $^{*}$ & 0 & 100 \\
\hline \multirow{2}{*}{ EDTA } & $5 \mathrm{mM}$ & 35.68 \\
\hline \multirow{2}{*}{ UREA } & $10 \mathrm{mM}$ & 33.92 \\
\hline N-bromosuccinimmide & $2 \mathrm{M}$ & 67.28 \\
\hline \multirow{2}{*}{ 3-mercaptoethanol } & $4 \mathrm{M}$ & 37.68 \\
\hline \multirow{2}{*}{ SDS } & $10 \mathrm{mM}$ & 0 \\
\hline \multirow{2}{*}{ Triton X-100 } & $10 \mathrm{mM}$ & 104.88 \\
\hline & $20 \mathrm{mM}$ & 108.72 \\
\cline { 2 - 3 } & 0.001 & 99.52 \\
\cline { 2 - 3 } & 0.002 & 111.76 \\
\hline \multirow{2}{*}{ Contro } & 0.001 & 99.84 \\
\cline { 2 - 3 } & 0.002 & 109.52 \\
\hline
\end{tabular}

${ }^{*}$ Control: enzyme activity measured in the absence of additives and inhibitors, assumed as $100 \%$

Table 5: Effect of various additives and inhibitors on the activity of $\alpha$-amylase.

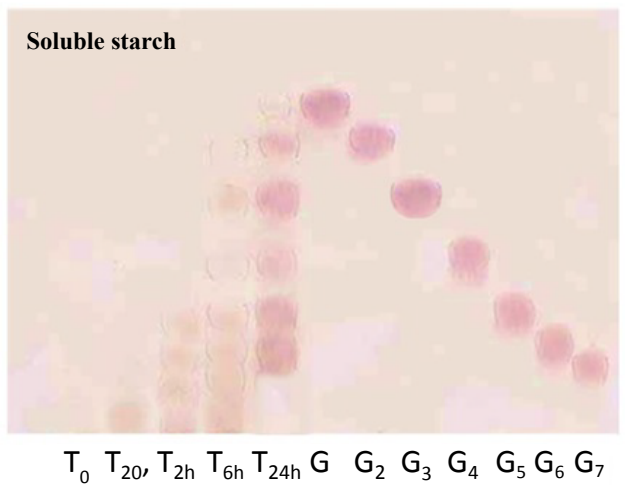

Figure 3: TLC analyses of reaction products of the purified amylase. From left to right, reaction products after $20 \mathrm{~min}, 2,6$ and $24 \mathrm{hrs}$ of incubation at $60^{\circ} \mathrm{C}$. G, glucose; G2, maltose; G3, maltotriose; G4, maltotetraose; G5 maltopentaose; G6, maltohexose; G7, maltoheptose were used as standards.

good candidate for applications in detergent industries. Finally, this enzyme was also sufficiently stable to the action of $2 \mathrm{mM}$ urea that caused only $30 \%$ loss of its activity.

\section{Study of hydrolysis products}

The Thin-Layer Chromatography (TLC) technique was used for analyzing of hydrolytic products of the enzyme action on soluble starch (Figure 3). When the enzyme was incubated with soluble starch, large malto oligosaccharides were produced during the early stage of reaction, as the reaction proceeded $(24 \mathrm{~h})$, the main hydrolysis products were maltoesose, maltopentaose, maltotriose. Maltopentaose (G5), maltose (G2) and maltotriose (G3) are the end products of starch hydrolysis by the $\alpha$-amylase of $B$. licheniformis $\mathrm{NH1}$ [34].

\section{Reuse of the entrapped amylase}

The immobilized crude enzyme showed the same behavior respect to the free enzyme. The entrapped amylase in alginate beads was evaluated by reusing beads for enzyme assay (after washing with distilled water) for several cycles. The a-amylase used in this study exhibited successful reuse. It maintained $48 \%$ of its initial activity after 6-time uses. It was found that its repeated reuse and starch hydrolysis ability were suitable for starchy processes. 
Citation: Finore I, Donato PD, Poli A, Kirdar B, Kasavi C, et al. (2014) Use of Agro Waste Biomass for a-Amylase Production by Anoxybacillus amylolyticus: Purification and Properties. J Microb Biochem Technol 6: 320-326. doi:10.4172/1948-5948.1000162

\section{Sequencing of $\alpha$-amylase}

The amyA gene sequence (1,724 bp) belonging to Anoxybacillus amylolyticus was deposited in Data Bank of Japan [DDBJ:AB908318].

\section{Conclusions}

Optimization of amylase production was tested in SmF and SSF conditions by using potato peel wastes, rhizome of Arundo donax and biomass from Cynara cardunculus. The cost of enzyme production in submerged fermentation conditions is high due to the need to use the very expensive synthetic media and from the ecological point of view for the higher water request. Therefore, the need to reduce the enzyme's production cost by alternative methods has prompted the search of cheaper alternative such as the exploitation of agro-wastes. In this study, rhizome of Arundo donax resulted to be a good substrate for amylase production in $\mathrm{SmF}$ thus allowing a cheaper alternative to obtain amylolytic enzymes. Indeed by using rhizomes from Arundo donax as growth substrate it was possible to recovery an amylase activity level higher than that obtained by synthetic complex medium. Amylase production was also investigated under SSF conditions by using the above listed wastes as sole carbon source for A. amylolyticus growth. Under these conditions, Cynara cardunculus gave a higher enzyme yield per reactor volume, encouraging for further studies on the optimization of process parameters under SSF conditions.

\section{Acknowledgement}

The authors are grateful to Massimo Fagnano and to Mauro Mori of the Agraria Department of "Federico II" University of Naples that kindly supplied $A$ donax and $C$. cardunculus waste biomass. This work has been implemented in the frame of the project PON01_01966 "Integrated agro-industrial chains with high energy efficiency for the development of eco-compatible processes of energy and biochemicals production from renewable sources and for the land valorization funded by MIUR.

\section{References}

1. Gupta R, Gigras P, Mohapatra H, Goswami VK, Chauhan B (2003) Microbia alpha-amylases: a biotechnological perspective. Process Biochem 38: 15991616.

2. Oliveira DS, Meherb-Dini C, Franco CM, Gomes E, Da-Silva R (2010) Production of crude xylanase from Thermoascus aurantiacus CBMAl 756 aiming the baking process. J Food Sci 75: C588-594.

3. Gangadharan D, Sivaramakrishnan S, Nampoothiri K M, Pandey A (2006) Solid culturing of Bacillus amyloliquefaciens for alpha amylase production. Food Technol Biotechnol 44: 269-274.

4. Rose's PR, Guerra NP (2009) Optimization of amylase production by Aspergillus niger in solid-state fermentation using sugarcane bagasse as solid support material. World J Microbiol Biotechnol 25: 1929-1939.

5. Pandey A, Soccol CR, Larroche C (2008) Current Developments in Solid-state Fermentation, Asia Tech Publishers, INC., New Delhi.

6. Pandey A, Soccol CR, Nigam P, Soccol VT (2000) Biotechnological potential of agro-industrial residues: sugar-cane bagasse. Bioresour Technol 74: 69-80.

7. Suryanarayan S (2003) Current industrial practice in solid state fermentations for secondary metabolite production: the Biocon India experience. Biochem Eng J 13: 189-195

8. Poli A, Esposito E, Lama L, Orlando P, Nicolaus G, et al. (2006) Anoxybacillus amylolyticus sp. nov., a thermophilic amylase producing bacterium isolated from Mount Rittmann (Antarctica). Syst Appl Microbiol 29: 300-307.

9. Finore I, Kasavi C, Poli A, Romano I, Oner ET, Kirdar B, Dipasquale L, Nicolaus B, Lama L (2011) Purification, biochemical characterization and gene sequencing of a thermostable raw starch digesting a-amylase from Geobacillus thermoleovorans subsp. stromboliensis subsp. nov. World J Microb Biot 27: 2425-2433.

10. Bradford MM (1976) A rapid and sensitive method for the quantitation of microgram quantities of protein utilizing the principle of protein-dye binding. Anal Biochem 72: 248-254.
11. Kasavi C, Finore I, Lama L, Nicolaus B, Oliver SG, Toksoy EO, Kirdar B (2012) Evaluation of Industrial Saccharomyces cerevisiae Strains for Ethano Production from Biomass. Biomass Bioenerg 45: 230-238.

12. Laemmli UK (1970) Cleavage of structural proteins during the assembly of the head of bacteriophage T4. Nature 227: 680-685.

13. Martínez TF, Alarcón FJ, Díaz-López M, Moyano FJ (2000) Improved detection of amylase activity by sodium dodecyl sulphate-polyacrylamide ge electrophoresis with copolymerized starch. Electrophoresis 21: 2940-2943.

14. Gupta MN, Dong G, Mattiasson B (1993) Purification of endo-polygalacturonase by affinity precipitation using alginate. Biotechnol Appl Biochem 18: 321-327.

15. Ramesh MV, Lonsane BK (1987) A novel bacterial thermostable alpha-amylase system produced under solid state fermentation. Biotechnol Lett 7: 501-504.

16. Anto H, Trivedi U, Patel K (2006) Alpha amylase production by Bacillus cereus MTCC 1305 using solid state fermentation. Food Technol Biotech 44: 241-245.

17. Hashemi M, Razavi SH, Shojaosadati SA, Mousavi SM, Khajeh K, et al. (2010) Development of a solid-state fermentation process for production of an alpha amylase with potentially interesting properties. J Biosci Bioeng 110: 333-337.

18. Kunamneni A, Permaul K, Singh S (2005) Amylase production in solid state fermentation by the thermophilic fungus Thermomyces lanuginosus. J Biosci Bioeng 100: 168-171.

19. Reda AB, Hesham MY, Mahmoud AS, Ebtsam ZA (2008) Production of bacteria pectinase(s) from agro-industrial wastes under solid state fermentation conditions. J App Sci Res 4(12): 1708-1721.

20. Nabi NG, Asgher M, Shah A H, Sheikh M A, Asad M J (2003) Production of pectinase by Trichoderma harzianum in solid state fermentation of citrus peel. Pak J Agri Sci 40: 3-4.

21. Ramachandran S, Patel AK, Nampoothiri KM, Francis F, Nagy V, et al. (2004) Coconut oil cake--a potential raw material for the production of alpha-amylase. Bioresour Technol 93: 169-174.

22. Baysal Z, Uyar F, Aytekin C (2003) Solid-state fermentation for production of a-amylase by a thermotolerant Bacillus subtilis from hot-spring water. Process Biochem 38: 1665-1668.

23. Sivaramakrishnan S, Gangadharan D, Nampoothiri K M, Soccol CR, Pandey A (2006) a-Amylases from Microbial Sources-An Overview on Recent Developments. Food Technol Biotechnol 44: 173-184.

24. Pandey A (1991) Effect of particle size of substrate on enzyme production in solid-state fermentation. Bioresource Technol 37: 169-172.

25. Elibol M, Moreira AR (2005) Optimization some factors affecting alkaline protease production by a marine bacterium Teredinobacter turnirae under solidstate substrate fermentation. Process Biochem 40: 1951-1956.

26. Hölker U, Lenz J (2005) Solid-state fermentation--are there any biotechnological advantages? Curr Opin Microbiol 8: 301-306.

27. Sajedi RH, Naderi-Manesh H, Khajeh K, Ahmadvand R, Ranjbar BA, et al (2005) A Ca-independent a-amylase that is active and stable at low $\mathrm{pH}$ from the Bacillus sp. KR-8104. Enzyme Microb Tech 36(5-6): 666-671.

28. Goh KM, Kahar UM, Chai YY, Chong CS, Chai KP, et al. (2013) Recent discoveries and applications of Anoxybacillus. Appl Microbiol Biotechnol 97: $1475-1488$.

29. Liu XD, Xu Y (2008) A novel raw starch digesting alpha-amylase from a newly isolated Bacillus sp. YX-1: purification and characterization. Bioresour Techno 99: 4315-4320.

30. Uyar F, Baysal ZM, Dogru M (2003) Purification and some characterization of an extracellular a-amylase from a thermotolerant Bacillus subtilis. Ann Microbiol 53: 315-322.

31. Özdemir S, Matpan F, Güven K, Baysal Z (2011) Production and Characterization of Partially Purified Extracellular Thermostable a-Amylase by Bacillus subtilis in Submerged Fermentation (SmF). Prep Biochem Biotechnol 41: 365-381.

32. Takasaki Y (1982) Production of Maltohexaose by alpha-Amylase from Bacillus circulans G-6. Agr Biol Chem 46: 1539-1547. 
Citation: Finore I, Donato PD, Poli A, Kirdar B, Kasavi C, et al. (2014) Use of Agro Waste Biomass for a-Amylase Production by Anoxybacillus amylolyticus: Purification and Properties. J Microb Biochem Technol 6: 320-326. doi:10.4172/1948-5948.1000162

33. Aguilar G, Morlon-Guyot J, Trejo-Aguilar B, Guyot JP (2000) Purification and characterization of an extracellular alpha-amylase produced by Lactobacillus manihotivorans LMG 18010(T), an amylolytic lactic acid bacterium. Enzyme Microb Technol 27: 406-413.
34. Hmidet N, Bayoudh A, Berrin JG, Kanoun S, Juge N, Nasri M (2008) Purification and biochemical characterization of a novel a-amylase from Bacillus licheniformis $\mathrm{NH} 1$ Cloning, nucleotide sequence and expression of amyN gene in Escherichia coli. Process Biochem 43: 499-505. 